\title{
Causes and Outcomes of Conflict Among the Workers at the Government Institutions: In the Case of Administrative Staff Wolaita Sodo University, Southern Ethiopia
}

\author{
Lidetu Alemu Anjulo (Assistant Professor) \\ Lecturer, Department of Management Wolaita Sodo University: P.O. Box: 138 Ethiopia
}

\begin{abstract}
For any organization to be effective and efficient in achieving its goals, the people in the organization need to have a shared vision of what they are striving to achieve, as well as clear objectives for each team/department and individual. The objective of this study was to asses Causes and outcomes of Conflict among the workers at the government institutions: The research was descriptive type and uses systematic random and purposive sampling techniques to drawn sample of 56respondents. The major identified causes of conflict in the organizations such as: goal incompatibility, difference in interest, differentiation, a task interdependence, scare resource, and Communication gap. Similarly, cultural background of workers, economic condition in market for salary and related staff benefits issues. In this case, Leaders should understand and apply various conflict management techniques appropriately and genuinely in order to form strong relationships with subordinates to achieve their institutional objectives and employees also should be aware of their organization conflict management strategies and create two-way communication. Therefore, this study concludes that Conflict is unavoidable and it is a situation when two or more parties are in disagreement and needs two way solutions for organizational effectiveness and efficiency.
\end{abstract}

Keywords: Conflict Management, Causes of conflict, Effectiveness and Efficiency

DOI: 10.7176/RHSS/9-5-05

Publication date:March $31^{\text {st }} 2019$

\section{INTRODUCTION}

People in the organization need to have a shared vision of what they are striving to achieve, as well as clear objectives for each team/department and individual. You also need ways of recognizing and resolving conflict amongst people, so that conflict does not become so serious that co-operation is impossible. All members of any organization need to have ways of keeping conflict to a minimum and of solving problems caused by conflict, before conflict becomes a major obstacle to your work (Herb Kindler 2005:216).

As noted in Alemu L (2018) in our diverse society, the possibility of these differences leading to conflict between individuals is always there, and we must be ready to act to preventing and resolving situations where conflict arises. People have different style of communication, ambitions, political or religious views and different cultural backgrounds. Even within one organization or team, conflict can arise from the individual differences or ambitions; or from rivalry between sub-groups or factions. All leaders and members of the organization need to be attentive to group dynamics that can spill over into conflict (Kindler.H 2006). Diversity management has been overestimated as the latest fad to occupy management discourse today. This shift to diversity management has been necessitated by the move away from the traditional labor intensive organizations to the modern globalised industries which rely on a diverse array of workers to meet organizational objectives (Nyamubarwa.W. andYusuf.M.2013).

Mujtaba.G. (2015.P.14) Organizations are collections of people who work together and coordinate their actions to achieve a wide variety of goals or desired future outcomes" (Jones \& George, 2014, p.5). A good manager should provide possibilities for his/her employees to coordinate and cooperate within the organization (Jones \& George, 2014, p.5). Learsers also need ways of recognizing and resolving conflict amongst people, so that conflict does not become so serious that co-operation is impossible (Vecchio.R 2003). Hotepo.M.O (2010) Conflicts are inevitable parts of organizational life since the goals of different stakeholders such as managers and staffs are often incompatible. (Schweiger. A. 1997). Der, B. C., (1978) .Conflict has both positive and negative effects (Jerome GP, 19764). It can be positive when it encourages creativity, new looks at old conditions, the clarification of points of view, and the development of human capabilities to handle interpersonal differences. (Tah.S.2015, Richard et al. (2009). Individual incompatibilities between the employees and in their groups can adversely affect their work output resulting in decreased performance (Eunice.M 2015).

\subsection{Statement of the Problem}

The traditional way of coping with conflict is to compromise, agreeing in part with the other person's view or demand. The biggest problem in developing the institutions of conflict control in organization is to develop an action of plan to identify conflicts at its initial stage (Hotepo.M.2010). As Herb Kindler (2005:216) there are 
effective conflict management techniques. Moreover, as noted in Alemu A (2018) Organizational conflict can be regarded as a dispute that occurs when interests, goals or values of different individuals or groups are incompatible with each other (Herry O.2009). This results into a situation whereby they frustrate each other in an attempt to achieve their objectives. Conflicts are expected part of organizational life since the goals of different stakeholders such as managers and staff are often incompatible Conflict is an unpleasant fact in any organization as longer as people compete for jobs, resources, power, recognition and security(Johns GR, 2000).

According to Kazimoto (2013), workplace conflict is described as the presence of discord that occurs when goals, interests or values of different individuals or groups are incompatible and frustrate each other's' attempt to achieve objectives in an organization. It is a communication process and an inevitable consequence of transactional relationship manifesting in disagreement and dissonance with and between individuals and groups in the workenvironment. In this context, workplace conflict is a fact of life in any organization as long as people will compete for jobs, power, recognition and security (Adomie and Anie, 2005). Therefore, the task of management is not to suppress or resolve all conflicts, but to manage them in order to enhance and not to detract from organizational performance (Longe.O.2015).

According to Sepehri M (2014) organizations face the challenges of keeping the delicate balance of satisfying both their guests' as well as their employees' need and demand without alienating one group versus the other. Working out and resolving the likely conflicts are mostly the responsibility of the hotelier. If hoteliers could prevent possible conflicts before they occur or if they find a stark solution, they would be successful and the business will gain and the moral would improve. As noted by Longe.O.(2015) Akanji (2005) opined that constructively managed conflict induces a positive performance, while destructively managed conflict heats up the work environment to bring about dislocation and polarization of the entire group with reduction in productivity and job performance. (Obasan.2011). Meggison\&Chung (1981) conflict raises in organizations the struggle between incompatible or opposing needs, wishes, ideas, interests or people. This means that conflict arises when individuals or groups encounter goals that both parties cannot attend sat factory.

The availability of few studies within the country Ethiopia has concentrated mainly on manufacturing industries and construction industries on conflict management issues. And the related research efforts are still passive in focusing on the on service sectors especially on Universities. As the result, this present study has an attempt to redress the situation by providing valuable insights to management in the service institutions and on the causes of Conflict and strategic importance of conflict management strategies as a resource tool for optimizing organizational performance. Based on the findings recommendations would have been given and expected that it greatly help the university to reduce their problems brought by conflicts.

\subsection{Research Questions}

In order to achieve the intended objective the researcher expected to answer the following research questions:

1. What are the major conflict management procedures that applied in your institution?

2. What are the contests of conflict management process in your organization?

3 . What are the major causes of the conflict in your organization?

4. What are the major results of the conflict that occurred in your organization?

5. What is the extent of top management involvement in addressing causes of conflict in your organization?

\subsection{Objective of the Study}

\subsubsection{General objectives}

The general objective of this study was to asses Causes and outcomes of Conflict among the workers at the government institutions: In the case of Administrative staff Wolaita Sodo University, Southern Ethiopia.

\subsubsection{Specific objectives}

1. To know the major conflict management procedures that applied in your institution

2. To address contests of conflict management process in your organization

3. To assess are the major causes of the conflict in your organization

4. To describe the major results of the conflict that occurred in your organization

5. To address the extent of top management involvement in addressing causes of conflict in your organization

\section{REVIEW OF RELATED LITERATURE}

\subsection{Sources/causes of conflict}

Early reviews in the field of conflict resolution identified a large number of schemes for describing sources or type of conflict (Fink, 1968; Mach and Snyder, 1958). One of the early theorists on conflict, Daniel Katz (1965), created a typology that distinguishes three main sources of conflict: economic, value, and power.

2.1.1. Economic Conflict involves competing motives to attain scarce resource. Each party wants to get the most that it can, and the behavior and emotions of each party are directed toward maximizing its gain. Union and 
management conflict often has as one of its source the incompatible goals of how to slice up the "economic pie" Ron Fisher (2000:118)

2.1.2. Value Conflict involves incompatibility in ways of life, ideologies - the preferences, principles and practices that people believe in. international conflict (e.g., the Cold War) often has a strong value component, wherein each side asserts the rightness and superiority of its way of life and its political-economic system

2.1.3. Power Conflict occurs when each party wishes to maintain or maximize the amount of influence that it exerts in the relationship and social setting. It is impossible for one party to be stronger without the other being weaker, at least in terms of direct influence over each other. Thus, a power struggle ensues which usually ends in a victory and defeat, or in a "stand - off" with a continuing state of tension. Power conflict can occur between individuals, between groups or between nations, wherever one or both parties since the parties are attempting to control each other (Prause.D.2015).

2.1.4. Goal Incompatibility: As Ron Fisher (2000:118) the name implies, goal incompatibility occurs when people or work units have goals that interfere each other. Financial reward for goal accomplishment further entrench the perceived conflict because employees are more motivated to pursue their own goals.

2.1.5. Differentiation: As Ron Fisher (2000:118) differentiation occurs when people hold divergent beliefs and attitudes due to their unique backgrounds, experiences, or training. For example, people in an organization have divergent technical backgrounds so they tend to see problems in organizations unwittingly fuel conflict by hiring people for their technical knowledge and encouraging them to become even more specialized.People in an organization also experience some conflicts arising from cultural differences. People from different cultural backgrounds may have difficult in understanding or accepting each other's beliefs and values, organization and events. Moreover, behaviors of people from different backgrounds are more easily misinterpreted. Daniel Katz $(1965)$,

2.1.6. Task Interdependence: As Ron Fisher (2000:119) Conflict tends to increase with the level of task interdependence. Task interdependence exists when team members must share common inputs to their work, or receive outcome (such as rewards) that are partly determined by the performance of others. The high the level of tasks interdependence, the great the possibility of conflict, because there is a greater chance that each side will disrupt or interfere with the other side's goals.

2.1.7. Scare Resource: According Ron Fisher (2000:201) scare resource resources generate conflict because scarcity motivates people party intends to interfere with the other party's goals. Employees enter a free-for-all battle to win decisions in their favor. When rules exist, on the other hand, everyone knows what to expect from each other and have agreed to abide by those rules.

2.1.8. Communication Problems: According Ron Fisher (2000:203)conflict often occurs due to the lack of opportunity, ability, or motivation to communicate effectively. First, when two parties lack the opportunity to communicate, they tend to use stereotypes to explain past behaviors and anticipate future actions. Unfortunately, stereotypes are sufficiently subject that emotions can negatively distort the meaning of an opponent's actions, thereby escalating perceptions of conflict. Moreover, without direct interactions, the two sides have less psychological empathy for each other. (Fink, 1968; Mach and Snyder, 1958).

\subsection{Conceptual Framework}

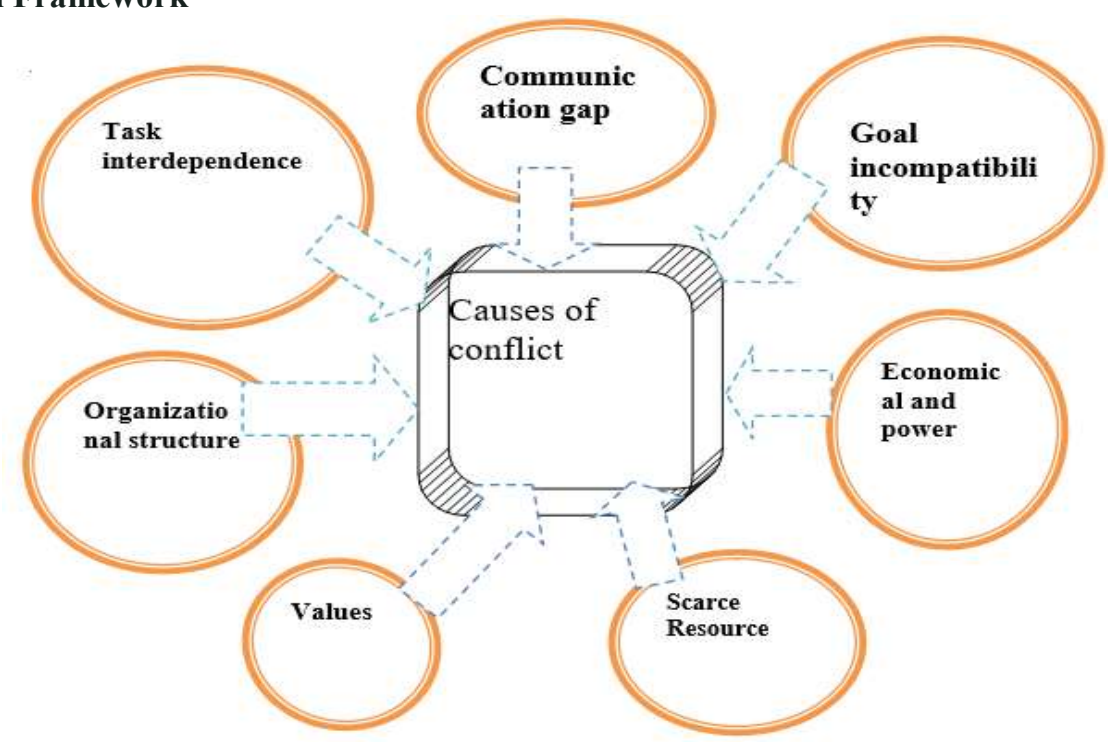

Figure 2.1:- Conceptual Framework

Source: Compiled by the Researcher (2019) 


\section{Research Design and Methodology \\ 3.1 Research Design}

The researcher used descriptive survey research design method. Because it helps to gather data at a particular point in time with intention of describing the nature of existing conditions, or identification standards against which existing conditions can be compared or determining the relationship that exists between specific events. In addition to this, it is used to gather data on a one shot basis and hence is economical and efficient (Mugenda \& Mugenda, 2003).

\subsection{Data Sources and Research Methods}

For this particular study primary data and secondary data were used. For primary data Questionnaire and interview were served and for the secondary data different sources of written materials were well revised and empirical evidences from different sources were being used.

\subsection{Population and Sample Size of the Study}

The target populations of this study include the staff of and workers of administrative staff of Wolaita Sodo University. The sampling techniques deployed systematic random sampling and purposive methods. The purposive sampling was employed in order to select workers who have more than 1 year work experiences in their respective offices.

\subsection{Data Analysis and Presentation}

Qualitative analysis consisted of examining, categorizing, tabulating and recombining evidences to address the research questions (Mugenda and Mugenda 2003). Qualitative data was analyzed descriptively through the use of questionnaires together with interview. For this end SPSS software version 20 was used.

\section{DATA ANALYSIS AND INTERPRETATION}

\subsection{Introduction}

Questionnaires were prepared and distributed to 60 employees, 56 were collected but the remaining 4 were uncollected. Based on the collected data from the workers of administrative office of the university and interview conducted to their supervisors, the following data analysis and interpretation was made.

Table 4 .1 Respondents background information

\begin{tabular}{|c|c|c|c|c|c|c|c|c|c|c|c|}
\hline \multirow[t]{2}{*}{ No. } & \multirow[t]{2}{*}{ Item } & \multicolumn{2}{|c|}{ Sex } & \multirow[t]{2}{*}{ No } & \multicolumn{3}{|c|}{ Marital status } & \multirow[t]{2}{*}{ No } & \multicolumn{3}{|c|}{ Facing conflict } \\
\hline & & No & Percentage & & Item & No & Percentage & & Item & No & Percentage \\
\hline \multirow[t]{3}{*}{1.} & Male & 36 & 64.3 & \multirow[t]{3}{*}{3.} & Married & 33 & 59.0 & \multirow[t]{3}{*}{5.} & Yes & 40 & 71.0 \\
\hline & Female & 20 & 35.7 & & Unmarried & 23 & 41.0 & & No & 16 & 29.0 \\
\hline & Total & 56 & 100 & & & 56 & 100 & & & & \\
\hline \multirow[t]{6}{*}{2.} & Age & No & Percentage & \multirow[t]{5}{*}{4.} & $\begin{array}{c}\text { Education } \\
\text { level }\end{array}$ & No & Percentage & \multirow[t]{5}{*}{6.} & $\begin{array}{l}\text { years } \\
\text { worked }\end{array}$ & No & Percentage \\
\hline & $\begin{array}{c}\text { Below } \\
20\end{array}$ & 15 & 26.7 & & $\begin{array}{c}\text { Primary } \\
\text { school }\end{array}$ & 19 & 33.9 & & $\begin{array}{l}\text { Below } 1 \\
\text { year }\end{array}$ & 10 & 17.9 \\
\hline & $21-30$ & 25 & 44.6 & & $\begin{array}{c}\text { Secondary } \\
\text { school }\end{array}$ & 20 & 35.7 & & $1-3$ & 13 & 23.2 \\
\hline & $\begin{array}{l}31-40 \\
\text { Years }\end{array}$ & 16 & 28.6 & & Certificate & 13 & 23.2 & & $3-5$ & 23 & 41.0 \\
\hline & $\begin{array}{c}\text { above } \\
40 \\
\end{array}$ & & & & $1^{\text {st }}$ Degree & 14 & 12.3 & & $\begin{array}{l}\text { More } \\
\text { than } 5\end{array}$ & 10 & 17.9 \\
\hline & Total & 56 & 100 & & & 56 & 100 & & & 56 & 100 \\
\hline
\end{tabular}

Source: Survey study 2019

As shown in the tables 4.1 above about (64.3\%) of the respondents were males while the rest of them are females. Regarding the marital status large number (59.0\%) is married and the rest are unmarried. For the issue of facing conflict large numbers of respondents $(71.0 \%)$ of respondents were faced conflict in their respective organizations and the rest were not. Regarding the work experience majority of the respondents $(41 \% \%)$ was worked for 3 to 5 years. 
Table 4.2 Sources of Conflict in the University

\begin{tabular}{|c|c|c|c|c|c|c|c|c|c|c|c|c|c|}
\hline \multirow[t]{3}{*}{ No } & \multirow[t]{3}{*}{ Distribution } & \multicolumn{10}{|c|}{ Sources/causes in the organizations } & \multicolumn{2}{|c|}{ Total } \\
\hline & & \multicolumn{2}{|c|}{$\begin{array}{l}\text { Very } \\
\text { high }\end{array}$} & \multicolumn{2}{|c|}{ High } & \multicolumn{2}{|c|}{ Medium } & \multicolumn{2}{|c|}{ Low } & \multicolumn{4}{|c|}{ Very Low } \\
\hline & & No & $\%$ & No & $\%$ & No & $\%$ & No & $\%$ & No & $\%$ & No & $\%$ \\
\hline 1. & Goal incompatibility & 26 & 46.4 & 14 & 25.0 & 10 & 17.9 & 5 & 8.9 & 1 & 1.8 & 56 & 100 \\
\hline 2. & Task interdependence & 17 & 30.4 & 13 & 23.2 & 12 & 21.4 & 7 & 12.5 & 7 & 12.5 & 56 & 100 \\
\hline 3. & Poor communication & 22 & 39.3 & 17 & 30.3 & 11 & 19.6 & 3 & 5.3 & 3 & 5.3 & 56 & 100 \\
\hline 4. & Poor performance & 20 & 35.7 & 11 & 19.6 & 9 & 16.0 & 10 & 17.9 & 5 & 8.9 & 56 & 100 \\
\hline 5. & $\begin{array}{l}\text { Personal problems of } \\
\text { workers }\end{array}$ & 27 & 48.0 & 13 & 23.2 & 10 & 17.9 & 3 & 5.3 & 2 & 3.6 & 56 & 100 \\
\hline 6. & $\begin{array}{l}\text { Resource related } \\
\text { conflict }\end{array}$ & 20 & 35.7 & 12 & 21.4 & 18 & 32.1 & 2 & 3.6 & 4 & 7.2 & 56 & 100 \\
\hline 7. & Power related conflict & 26 & 46.4 & 14 & 25.0 & 10 & 17.9 & 3 & 5.3 & 2 & 3.6 & 56 & 100 \\
\hline 8. & $\begin{array}{ll}\text { Rumors } & \text { and } \\
\text { intolerance } & \end{array}$ & 24 & 42.9 & 16 & 28.6 & 10 & 17.9 & 2 & 3.6 & 3 & 5.4 & 56 & 100 \\
\hline 9. & Values/interest related & 27 & 48.2 & 13 & 23.2 & 8 & 14.3 & 4 & 7.1 & 4 & 7.1 & 56 & 100 \\
\hline 10. & $\begin{array}{l}\text { Organizational } \\
\text { structure }\end{array}$ & 23 & 41.0 & 15 & 26.8 & 12 & 21.4 & 3 & 5.3 & 2 & 3.6 & 56 & 100 \\
\hline 11. & Financial reward & 25 & 44.6 & 15 & 26.8 & 10 & 17.9 & 3 & 5.3 & 2 & 3.6 & 56 & 100 \\
\hline 12. & Unfair promotion & 20 & 35.7 & 15 & 26.8 & 15 & 26.8 & 4 & 7.1 & 2 & 3.6 & 56 & 100 \\
\hline
\end{tabular}

Source: Survey study 2019

As described in the table above (4.1) majority of the respondents (46.4\%) stated that their cause of conflict in their organization is goal difference is very high and also $(25 \%)$ stated that the probability of occurrence of goal related conflict is high. In other ways the conflict because of task interdependence is also very high (30.4\%). The problem of Poor communication occurred also with high number $(39.3 \%)$. Majority $(35.7 \%)$ described that the other side cause of conflict in their organization is because of poor performance of employees. On the other hand majority of the respondents $(35.7 \%)$ the other most cause of conflict in their organization is resource related and. Values and interest difference among employees, large number of respondents (48.2) accepted values and interest difference among employees. In addition to these, organizational structure is also the other source of conflict, among the respondents $(41.0 \%)$ accepted it as high.

Furthermore, majority of the respondents said that there is very high conflict related to power (46.4\%) and rumors and intolerance among employees also accounts high coverage (42.9\%). During the interview the managers of hotel stated their opinion that, their other challenge in conflict management is informal communication and rumors. And regarding financial reward, large number of respondents $(44.6 \%)$ gave their answer to the other root cause which is related to reward system of their organization. The issue of fairness in promotion considered majority $(35.7 \%)$ stated that their other side cause of conflict is unfair treatment of employees in promotion process. 
Table 4.2: Conflict Management strategies implemented

\begin{tabular}{|c|c|c|c|c|c|c|c|c|c|c|c|c|c|}
\hline \multirow[t]{3}{*}{ No } & \multirow[t]{3}{*}{ Distribution } & \multicolumn{10}{|c|}{ Conflict Management strategies practices } & \multicolumn{2}{|c|}{ Total } \\
\hline & & \multicolumn{2}{|c|}{$\begin{array}{l}\text { Highly } \\
\text { satisfied }\end{array}$} & \multicolumn{2}{|c|}{$\begin{array}{l}\text { Low } \\
\text { satisfaction }\end{array}$} & \multicolumn{2}{|c|}{ Medium } & \multicolumn{2}{|c|}{ Unsatisfied } & \multicolumn{4}{|c|}{$\begin{array}{l}\text { Highly } \\
\text { unsatisfied }\end{array}$} \\
\hline & & No & $\%$ & No & $\%$ & No & $\%$ & No & $\%$ & No & $\%$ & No & $\%$ \\
\hline 1. & $\begin{array}{l}\text { Negotiation } \\
\text { strategies }\end{array}$ & 1 & 1.8 & 3 & 5.3 & 10 & 17.9 & 16 & 28.6 & 18 & 32.1 & 56 & 100 \\
\hline 2. & On time decision & 7 & 12.5 & 10 & 17.9 & 12 & 21.4 & 11 & 19.6 & 22 & 39.3 & 56 & 100 \\
\hline 3. & $\begin{array}{l}\text { Smoothing } \\
\text { potential causes }\end{array}$ & 3 & 5.3 & 3 & 5.3 & 11 & 19.6 & 13 & 23.2 & 20 & 35.7 & 56 & 100 \\
\hline 4. & $\begin{array}{l}\text { Accommodation } \\
\text { strategy }\end{array}$ & 5 & 8.9 & 2 & 3.6 & 9 & 16.0 & 12 & 21.4 & 27 & 48.0 & 56 & 100 \\
\hline 5. & $\begin{array}{l}\text { Avoiding as an } \\
\text { issue }\end{array}$ & 2 & 3.6 & 3 & 5.3 & 10 & 17.9 & 14 & 25.0 & 20 & 35.7 & 56 & 100 \\
\hline 6. & $\begin{array}{l}\text { Competing as the } \\
\text { strategy }\end{array}$ & 4 & 7.2 & 2 & 3.6 & 18 & 32.1 & 16 & 28.6 & 26 & 46.4 & 56 & 100 \\
\hline 7. & $\begin{array}{l}\text { Compromising as } \\
\text { the strategy }\end{array}$ & 2 & 3.6 & 4 & 7.1 & 10 & 17.9 & 13 & 23.2 & 24 & 42.9 & 56 & 100 \\
\hline 8. & $\begin{array}{l}\text { Collaborating as a } \\
\text { strategy }\end{array}$ & 3 & 5.4 & 3 & 5.3 & 10 & 17.9 & 15 & 26.8 & 27 & 48.2 & 56 & 100 \\
\hline 9. & $\begin{array}{l}\text { Forcing: pushing } \\
\text { one's own view on } \\
\text { others }\end{array}$ & 4 & 7.1 & 3 & 5.3 & 8 & 14.3 & 15 & 26.8 & 23 & 41.0 & 56 & 100 \\
\hline 10. & $\begin{array}{l}\text { Formal discussion } \\
\text { among workers }\end{array}$ & 2 & 3.6 & 4 & 7.1 & 12 & 21.4 & 15 & 26.8 & 25 & 44.6 & 56 & 100 \\
\hline
\end{tabular}

Source: Survey study 2019

As shown in the table above (table 4.2$)$ majority of the respondents $(32.1 \%)$ were highly dissatisfied by the negotiation strategies of their organization and $(28.6 \%)$ were dissatisfied by their management strategies. Regarding on time decision by managers large number (39.3\%) were highly dissatisfied. Besides to this manager's responded in interview that in fact they are not giving on time decision for employees because of their work load and related problems. Regarding Smoothing potential causes of conflict, large number (35.7\%) were unsatisfied. Whereas, to the issue of an accommodation with managers $(48.0 \%)$ of the respondents reveals that there is low avoidance strategy. Regarding Competing as the strategy, large number of the respondents (46.4\%) were dissatisfied and compromising strategy majority $(28.6 \%)$ was unsatisfied. From this we can easily understand that the competing strategy is highly practiced that and compromising strategies. Majority of the respondents (48.2\%) are highly dissatisfied by collaborating strategy. These imply that the management does not find solution which is more collaborating with employees even if the respondents' response is optimum. In addition to this, the manager's response for interview, they agreed that there is medium collaborating conflict management techniques are applied in selected hotels. These imply that the management does not find solution which is more collaborating with employees even if the respondents' response is optimum. Regarding Forcing/pushing one's own view on others, for about (44.6\%) of the respondents was highly dissatisfied by the strategies and for about (33.3\%) was unsatisfied.

\section{SUMMARY OF FINDINGS, CONCLUSION AND RECOMMENDATIONS}

This chapter summarizes and concludes the findings of the research and forward possible recommendations.

\subsection{SUMMARY OF FINDINGS AND CONCLUSION}

$>$ There are distinguished three main sources of conflict: economic, value, and power. In addition to these causes there are also other major causes of conflict in the organizations such as: goal incompatibility, Differentiation, a Task Interdependence, Scare Resource, and Communication Problems. Similarly, cultural background of workers, economic condition in market for salary and the other related staff benefits issues scare resources generate conflict because scarcity motivates people party intends to interfere with the other party's goals and conflict also often occurs due to the lack of opportunity, ability, or motivation to communicate effectively. Moreover, the major causes of conflict in this institution are related to differences in interest, rumors and lack of good communication among workers and supervisors or office head.

Based on the findings of the study, the researcher come up with conclusion that the university top management and officials were not using conflict resolution strategies genuinely and appropriately, these results in high dissatisfaction of employees in their workplace and leads the employees even to perceive 
that the outcome of conflict in the organizations is negative always. These all elements results in the negative impact on the university effectiveness and also on employees moral and performance. In addition to these facts, it results in the high employee turnover, less integrity among workers, bad reputation on the university; fail to achieve organizational goal and objectives in the planned period.

\subsection{RECOMMENDATIONS}

The following recommendations are forwarded to the university officials and workers supervisors and workers in order to solve causes of conflict related problems.

* For the efficiency and effectiveness of the University, the university management bodies and supervisors should develop skills such as: managers be aware and respect employees differences, they have to develop appealing procedure for workers, changing personnel, changing organizational structure and the ability to seek compromise and avoid punishing, focus on root causes of conflict, make all participative decisions, calm in emotion. In addition to these solutions, the supervisors should also develop the management behaviors such as: should give enough time to workers and discuss on causes and solutions of conflict, counsel and train their employees to minimize conflict cause, consequences and resolution techniques, advise and communicate with employees and develop effective two-way communication, so that the employees be responsible to do their best.

* In fact, some of the best solutions to conflict problems come from working through and properly managing conflict. However, mismanaged conflict can result in bad outcomes, and even really ugly ones. So this needs the manager's skill how to manage the cause and consequences of conflict. Moreover, Supervisor should use and implement the different types of conflict management strategies like Avoiding, Accommodating, Competing, Compromising, Collaborating, negotiation and smoothing. To be effective and efficient on their sectors they have use these strategies genuinely, appropriately and as situation as needed.

\section{REFERENCES}

Baba, M. L., Gluesing, J., Ratner, H., \& Wagner, K. H. (2004). The contexts of knowing: Natural history of a globally distributed team. Journal of Organizational Behavior, 25 (5), 547-587. Retrieved on October 23, 2012 from EBSCOhost database.

Chiravurl A., Narareth D., \& Ramamurthy K., (2011). Cognitive conflict and consensus generation in virtual teams during knowledge capture: Comparative effectiveness of techniques. Journal of Management Information Systems, 8 (1), 311-350. Retrieved on October 2, 2012 from EBSCOhost database.

Desivilya H. S., Somech A., Lidgoster H., (2010) Innovation and conflict management in work teams: The effects of team identification and task and relationship conflict. International Association for Conflict Management. 3, (1), 28 - 48. Retrieved from Wiley Periodicals, Inc. on October 22 $2^{\text {nd }}, 2012$.

Hardin, A. M., Fuller, M. A., \& Davison, R. M. (2007). I Know I Can, But Can We?: Culture and Efficacy Beliefs in Global Virtual Teams. Small Group Research, 38, 130-155. Retrieved from Wiley Periodicals, Inc. on October $22^{\text {nd }}, 2012$

Fiol M. C., Pratt M. G., O’Connor E. J., (2009). Managing intractable indentity conflicts. Academy of Management Review, 34, (1), 32-55. Retrieved on the October 17, 2012 from JSTOR.

Francesco A. M., Gold B. A., (2005). International organizational behavior: texts, cases, and skills. Chapter Four: Communication. Pearson Prentice Hall. Upper Saddle River, NJ. (69-85).

Jarvenpaa, S. L., \& Leidner, D. E. (1999). Communicationand trust in global virtual teams. Organization Science, 10 (6), 791-815. Retrieved from Wiley Periodicals, Inc. on October 22 ${ }^{\text {nd }}, 2012$.

Jarvenpaa S. L, Knoll K., and Leidner D. E., (1998). Is Anybody out There? Antecedents of Trust in Global Virtual Teams. Journal of Management Information Systems 14, (4), 29-64. Retrieved on October 23, 2012 from EBSCOhost database.

Kankanhalli A., Tan B. C. Y. \& Wei K. (2006). Conflict and performance in global virtual teams. Journal of Management Information Systems, 23 (3), 237-274. Retrieved on October 2, 2012 from EBSCOhost database.

Kenneth T. W. (1992). Conflict and conflict management: Reflections and update. Journal of Organizational Behavior, 13 (3), 265-274. Retrieved on October, 2012 from JSTOR.

Kristof, A.L., Brown, K. G, Sims Jr., H. P., \& Smith, K. A. (1995). The virtual team: A case study and inductive model. In M. M.Beyerlein, D.A.Johnson and S. T.Beyerlein, (Eds.), Advances in interdisciplinary studies of work teams: Knowledge work in teams, 2, 229-253. Greenwich, CT : JAI Press.

Alemu A (2018). Organizational Conflict Management Strategies of Hotel sectors in Ethiopia: Employees perception on the practices in case of selected Hotels in Wolaita Sodo Town, Southern Ethiopia. The international journal of business and managenet. Vol6,issue 1

Maznevski, M. L. and Chudoba, K. M. "Bridging Space Over Time: Global Virtual Team Dynamics and Effectiveness," Organization Science, 11, 2000, 473- 492. Retrieved from Wiley Periodicals, Inc. on October $22^{\text {nd }}, 2012$ 
Melin M. M., (2011). The impact of state relationships on if, when, and how conflict management occurs. International Studies Quarterly 55, 691-715. Retrieved on October 12, 2012 from EBSCOhost database.

Ratcheva V., (2008). The knowledge advantage of virtual teams: Processes supporting knowledge synergy. Journal of General Management, 33 (3), 53-67. Retrieved on October 2, 2012 from EBSCOhost database.

Ron Fisher (2000). International Peace and Conflict Resolution, $3^{\text {rd }}$ edition, The American University

Rusell P, Jerome GP, 1976. Conflicts in organization: good or bad. Air University Review, 13(8): 13-21.

Robert RB, Jane SM, 1969. Building a dynamic corporation through Grid Organization development; AddisonWesley Publishing Company, Reading. ISBN - 13: 978-0201006124

Stephen Probbins (2005). Essential of Organization Behavior, 8 editions New York.

Thomas K.W., Kilmann R.H. (1974, 2007). Thomas-Kilmann Conflict Mode Instrument.

Mountain View, CA: CPP Inc, Partly retrieved on August 18, 2014,fromhttp://www.kilmanndiagnostics.com/overview-thomas-kilmann-conflict mode instrument-tki.

Uchendu, C. Anijaobi, F. \& Odigwe, F. (2013). Conflict Management and Organizational Performance in Secondary Schools in Cross Rivers State. Nigeria Research Journal in Organizational Psychology and Educational Studies, 2(2), 67-71.2 (1): 16-24 